\title{
An Investigation of Glyceollin I's Inhibitory Effect on The Mammalian Adenylyl Cyclase
}

\author{
Dong-Chan Kim*, Nam Doo Kim², Sung In Kim', Chul-Soo Jang', Chang Oh Kweon', Byung Weon Kim, \\ Jae-Ki Ryu', Hyun-kyung Kim', Suk Jun Lee', Seungho Lee ${ }^{3}$ and Dongjin Kim \\ ${ }^{1}$ Department of Biomedical Laboratory Science, Gimcheon University, Gimcheon 740-704, Korea \\ ${ }^{2}$ Daegu-Gyeongbuk Medical Innovation Foundation, New Drug Development Center, Daegu 706-010, Korea \\ ${ }^{3}$ Department of Oriental Rehabilitation Medicine, Gimcheon University, Gimcheon 740-704, Korea \\ ${ }^{4}$ School of Civil and Environmental Engineering Georgia Institute of Technology, Atlanta, Georgia, U.S.A.
}

Received March 23, 2013 /Revised April 29, 2013 /Accepted May 9, 2013

\begin{abstract}
Glyceollin I has gained attention as a useful therapy for various dermatological diseases. However, the binding property of glyceollin I to the mammalian adenylyl cyclase (hereafter mAC), a critical target enzyme for the down-regulation of skin melanogenesis, has not been fully explored. To clarify the action mechanism between glyceollin I and $\mathrm{mAC}$, we first investigated the molecular docking property of glyceollin I to $\mathrm{mAC}$ and compared with that of SQ22,536, a well-known mAC inhibitor, to $\mathrm{mAC}$. Glyceollin I showed superiority by forming three hydrogen bonds with Asp 1018, Trp 1020, and Asn 1025, which exist in the catalytic site of mAC. However, SQ22,536 formed only two hydrogen bonds with Asp 1018 and Asn 1025. Secondly, we confirmed that glyceollin I effectively inhibits the formation of forskolin-induced cAMP and the phosphorylation of PKA from a cell-based assay. Long term treatment with glyceollin I had little effect on the cell viability. The findings of the present study also suggest that glyceollin I may be extended to be used as an effective inhibitor of hyperpigmentation.
\end{abstract}

Key words : Glyceollin I, mammalian adenylyl cyclase, SQ22536, melanogenesis, computation modeling

\section{Introduction}

Skin-pharmacotherapy is a continually expanding field in the cosmeceutical industry. Novel drug investigators are developing sensitive cosmeceutical candidates that target specific receptors in the skin cells to elicit concerted and appropriate biological responses. Melanin is the main target for skin pharmacotherapy, and is synthesized in special organelles called melanosomes that play a pivotal role in protecting skin from deleterious sunlight under normal conditions [7]. Melanin synthesis is stimulated by a large number of effectors, including ultraviolet B radiations, forskolin, IBMX, and alpha-MSH [4]. The major signaling pathway leading to melanin synthesis appears to be stimulation of adenylyl cyclase followed by an increase in the cAMP level and acti-

\footnotetext{
*Corresponding author

Tel : +82-54-420-4041, Fax : +82-54-420-4461

E-mail : jenokin@nate.com

This is an Open-Access article distributed under the terms of the Creative Commons Attribution Non-Commercial License (http://creativecommons.org/licenses/by-nc/3.0) which permits unrestricted non-commercial use, distribution, and reproduction in any medium, provided the original work is properly cited.
}

vation of cAMP-dependent protein kinases A (PKAs) [3] Therefore, the inhibitors of the melanogenesis via blocking adenylyl cyclase activity and its signaling pathway, particularly from natural phytochemical sources, can be of a great interest to cosmeceutical industries.

Glyceollin I is one of a group of phytoalexins produced in soybeans under stress conditions [3]. In previous study, glyceollin I showed anti-microbial, anti-estrogenic, and anti-tumor activity $[5,12]$. However, the exact binding target of glyceollin I on anti-melanogenesis have not been evaluated to date.

Mammalian adenylyl cyclase (mAC) is a 12-transmembrane protein that catalyzes the conversion of ATP to CAMP upon the stimulation of various G-protein coupled receptors[6]. $\mathrm{mAC}$ has various isoforms and all nine membrane-bound $\mathrm{mAC}$ isoforms are activated by GTP-bound $\mathrm{Ga}$ $s$ and the plant diterpene forskolin [10].

In the present study, we evaluated the binding property of glyceollin I to the active site of mAC and the inhibitory activity of glyceollin I to mAC-induced signaling pathways. Using the well-characterized computation modeling system and B16F10 mammalian melanoma cells, we attempted to 
determine the interaction mechanisms and inhibitory effect of glyceollin I to mAC enzyme comparing with those of SQ22,536 (a well known mAC blocker).

\section{Materials and Methods}

\section{Docking Method}

For the binding model prediction of Glyceollin I and SQ22,536 with human $\mathrm{mAC}$, we used the crystal structured mAC with 2'(3')-O-(N-methylanthranyloyl)-guanosine-5-triphosphate (MASNT-GTP) complex from Protein Data Bank (PDB code 1U0H). The Glyceollin I and SQ22,536 were built using Maestro build panel and energy minimized by the Impact module in the Schrödinger software package. The starting coordinate of human mAC was further modified for docking calculation. The protein structure was minimized using the Protein Preparation Wizard by applying an OPLS force field. For the grid generation, the binding site was defined as the centroid of the MANT-GTP. Ligand docking into the catalytic site of human $\mathrm{mAC}$ was carried out using the Schrödinger docking program, Glide. The energy minimized Glyceollin I and SQ22,536 were docked into the prepared receptor grid. The best-docked poses were selected as the lowest Glide score. The molecular graphics for the refined docking model of Glyceollin I and SQ22,536 were generated using PyMol package (http://www.pymol.org).

\section{Reagents}

Glyceollin I was isolated following the procedure developed by Boué et al. [1]. Forskolin, MTT and other chemical reagents were purchased from Sigma Chemical Co. (St. Louis, MO, USA.). $\left.{ }^{3} \mathrm{H}\right] \mathrm{cAMP}$ was purchased from PerkinElmer Life and Analytical Sciences (Boston, MA). Antibodies against pPKA and $\beta$-actin were purchased from Santa Cruz Biotechnology (Santa Cruz, CA, USA). Polyvinylidene difluoride (PVDF) membranes were obtained from Millipore (Bedford, MA, USA).

\section{Cell culture}

B16F10 cells, purchased from Korean Cell Line Bank (Seoul, Korea), were cultured in DMEM with 10\% fetal bovine serum (FBS; Gibco, NY, USA.) and penicillin/streptomycin $(100 \mathrm{IU} / 50 \mu \mathrm{g} / \mathrm{ml})$ in a humidified atmosphere containing $5 \% \mathrm{CO}_{2}$ in air at $37^{\circ} \mathrm{C}$. B16 cells were cultured in 24-well plates for each assay. All the experiments were per- formed in triplicate and repeated three times to ensure reproducibility.

\section{Measurement of $\left[{ }^{3} \mathrm{H}\right] \mathrm{CAMP}$}

Intracellular cyclic AMP generation was determined by $\left[{ }^{3} \mathrm{H}\right]$ cAMP competition assay in binding to cyclic AMP-binding protein as described previously by Kim et al. [11] with some modification. To determine the cyclic AMP production induced by forskolin, the B16 cells were stimulated with agonists for $20 \mathrm{~min}$ in the presence of the phosphodiesterase inhibitor Ro $20-1724(5 \mu \mathrm{M})$ and the reaction was quickly terminated by three repeated cycles of freezing and thawing. The samples were then centrifuged at 2,500 $\mathrm{g}$ for $5 \mathrm{~min}$ at $4^{\circ} \mathrm{C}$. The cyclic AMP assay was based on the competition between $\left[{ }^{3} \mathrm{H}\right]$-labeled cyclic AMP and unlabeled cyclic AMP present in the sample for binding to a crude cyclic AMP-binding protein prepared from bovine adrenal cortex according to the method of Brown et al. [2]. Each sample was incubated with $5 \mu \mathrm{l}$ of $\left[{ }^{3} \mathrm{H}\right]$-labeled cyclic AMP $(5 \mathrm{mCi})$ and $100 \mathrm{\mu l}$ of binding protein for $2 \mathrm{~h}$ at $4^{\circ} \mathrm{C}$. Separation of the protein-bound cyclic AMP from the unbound cyclic AMP was achieved by the adsorption of the free cyclic AMP

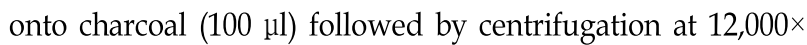
$g$ at $4^{\circ} \mathrm{C}$. The $200 \mu \mathrm{l}$ of supernatant were then placed into an Eppendorf tube containing $1.2 \mathrm{ml}$ of scintillation cocktail to measure the radioactivity. The cyclic AMP concentration in the sample was determined based on a standard curve and expressed as pmol per number of cells.

\section{Determination of glyceollin I for cell viability}

The cell viability assay was performed as described in the previous study using 3-(4,5-dimethylthiazol-2-yl)-2,5-diphenyltetrazolium bromide (MTT) [14]. Shortly thereafter, $5 \times 10^{4}$ B16F10 cells/well were plated in a 24-well plate. After cells were exposed to glyceollin I at the concentration of $3 \mu \mathrm{M}$ for $48 \mathrm{~h}$, MTT solutions were added and the insoluble derivative formed by cellular dehydrogenase was solubilized with ethanol - dimethyl sulfoxide (DMSO) (1:1 mixture solution); the absorbance of each well was read at $560 \mathrm{~nm}$ using a microplate spectrophotometer.

\section{Western blot analysis}

Whole cell protein extracts were separated by $10 \%$ SDS-PAGE and transferred to PVDF membranes at $15 \mathrm{~V}$ for $1 \mathrm{~h}$ in a semi-dry transfer system. The membrane was immediately placed into blocking buffer ( $5 \%$ non-fat milk) 
containing $10 \mathrm{mM}$ Tris (pH 7.5), $100 \mathrm{mM} \mathrm{NaCl}$, and $0.1 \%$ Tween 20. The blot was blocked at room temperature for $30 \mathrm{~min}$. The membrane was then incubated with specific primary antibody at $4^{\circ} \mathrm{C}$ overnight, followed by incubation with secondary antibody at room temperature for $1 \mathrm{~h}$. Antibody labeling was detected by using SUPEX ECL solution Kit (NEURONEX, Goryeong, South Korea). Pre-stained protein markers were used for molecular weight determination.

\section{Statistical analysis}

The values are expressed in the standard error of the mean $(n=3)$ and the biological significance $p<0.05$ was determined by the Student's $t$-test.
Results

\section{Analysis of the proposed binding model}

We investigated the proposed binding model of glyceollin I (Fig. 1 and Fig. 2) and SQ22,536 (Fig. 3) with mAC. The results from the docking studies suggested that hydrogen bonds play important role in the inhibition activity between glyceollin I and polar side chain of mAC. As shown in Fig. 2, the docking model of Glyceollin I with mAC indicated that glyceollin I interacts with the catalytic site of mAC (i.e., the hydrogen bonds of Asp 1018, Trp 1020, and Asn 1025 with glyceollin I). While, the possible hydrogen bond interactions involve the side chain of Asp 1018 and Asn 1025 in the proposed docking model of SQ22,536 with

B

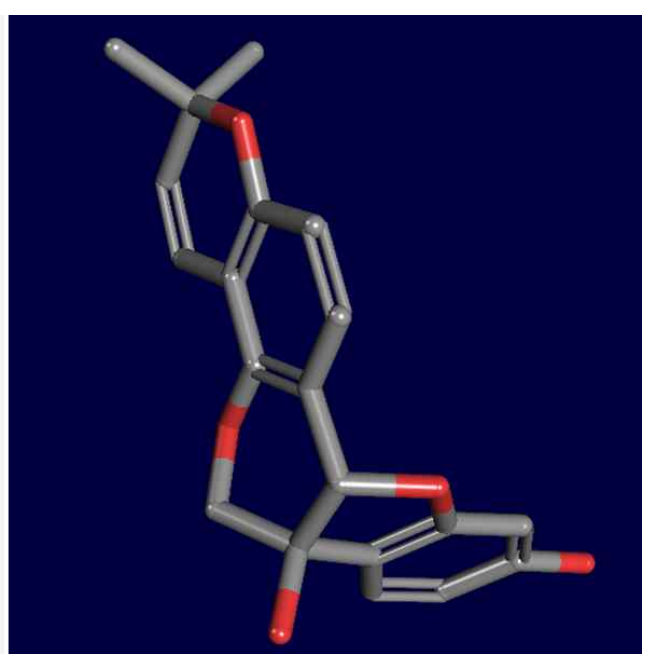

Fig. 1. Chemical structure of Glyceollin I (A) 2D structure of Glyceollin I and (B) 3D structure of Glyceollin I (Pictures are from Pubmed Chem Compund ID: 162807).

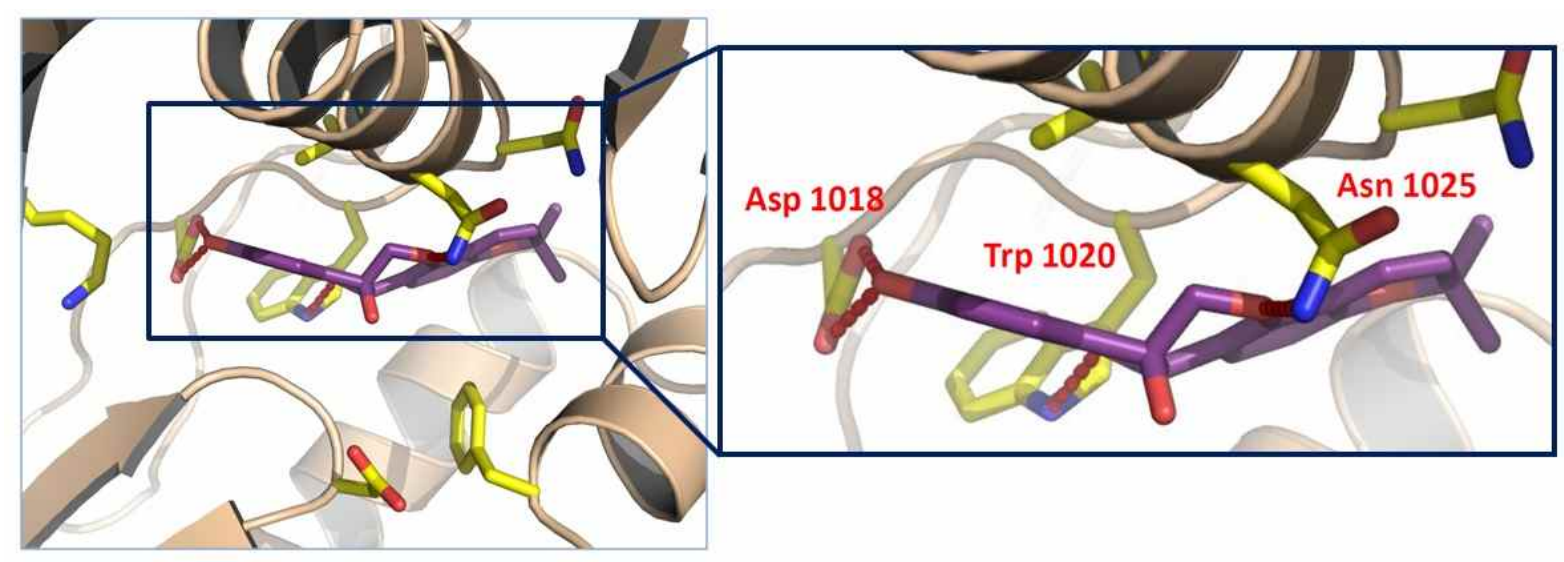

Fig. 2. Proposed binding model of Glyceollin I on mAC. This figure depicts the molecular structure of docked ligand with crystal structure with active site residues in stick form and hydrogen bond with red color dashes line. 
A<smiles>Nc1ncnc2c1ncn2C1CCCO1</smiles>

B

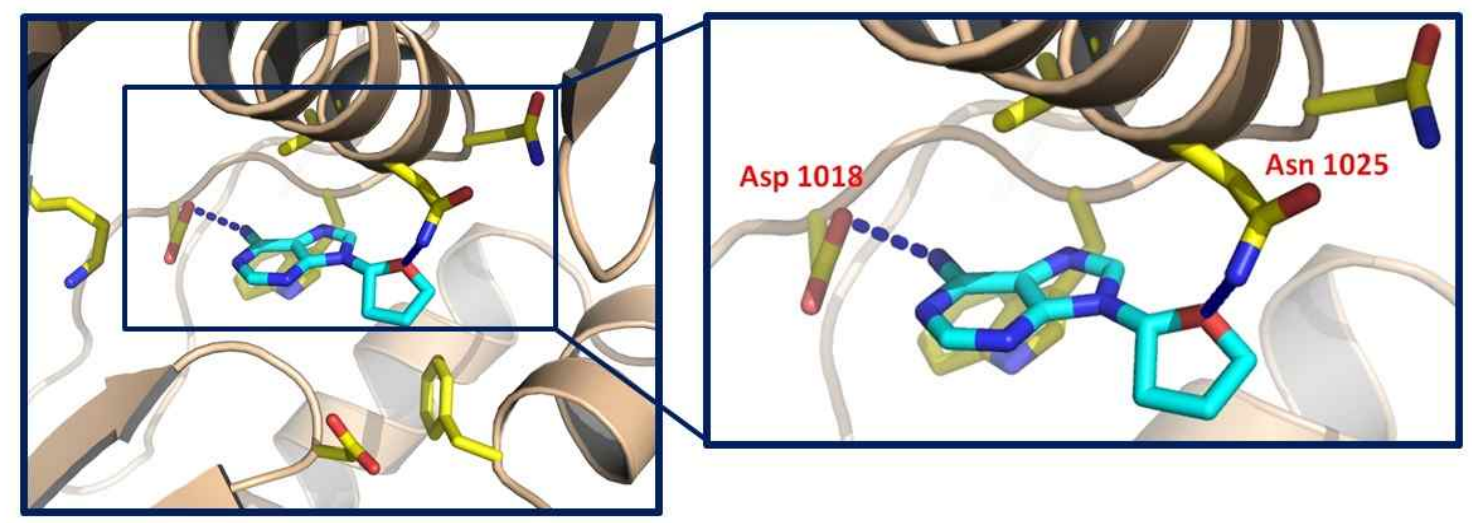

Fig. 3. (A) Chemical structure of SQ22,536 and (B) Proposed binding model of SQ22536 on mAC. These figures depict the molecular structures of docked ligand with crystal structure with active site residues in stick form and hydrogen bond with blue color dashes line.

mAC (Fig. 3).

Inhibitory action of glyceollin I on forskolin-induced CAMP production

Forskolin is the first main labdane diterpenoid purified from the roots of the Indian Plectranthus barbatus ANDREWS and one of the most extensively studied ingredients of this plant. The unique character of forskolin as a general direct, reversible, and rapid activator of $\mathrm{mAC}$ not only underlies its wide range of pharmacological effects but also renders it as a valuable tool in the study of the role of cAMP. To check whether glyceollin I directly blocks mAC activity in living cellular system, we chose the B16F10 melanoma cells and investigated the glyceollin I's inhibitory effect. $5 \mathrm{~min}$ pretreatment of glyceollin I showed strong inhibitory effect on forskolin-induced cAMP production in a concentration-dependent manner (Fig. 4). Besides, glyceollin I $\left(\mathrm{IC}_{50}=0.5 \pm 0.1 \mu \mathrm{M}\right)$ showed stronger inhibitory effect than SQ22,536 ( $\left(\mathrm{IC}_{50}=1.0 \pm 0.4 \mu \mathrm{M}\right)$ (Fig. 4). These data suggest that glyceollin I directly inhibits cAMP production signaling pathways via blocking the active site of the mAC.

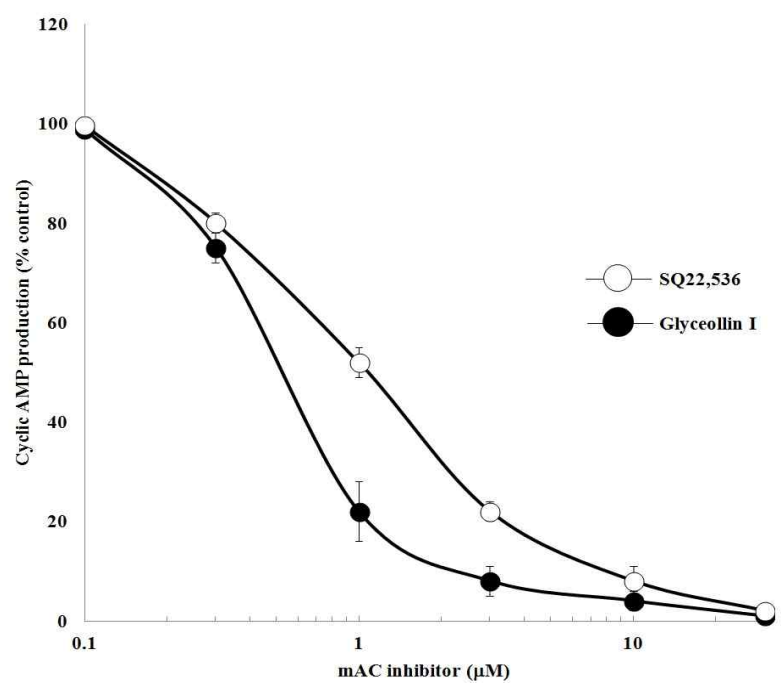

Fig. 4. The inhibition of forskolin-induced cAMP production with the increase in the concentration of $\mathrm{MAC}$ inhibitor (Glyceollin I and SQ22,536) pretreatment. B16F10 cells were preincubated with various concentrations of $\mathrm{mAC}$ blocker for $5 \mathrm{~min}$, then cells were stimulated with forkolin $(1 \mu \mathrm{M})$, respectively. The data are in the standard error of the mean of the assay triplicates with at least six independent experiments. 


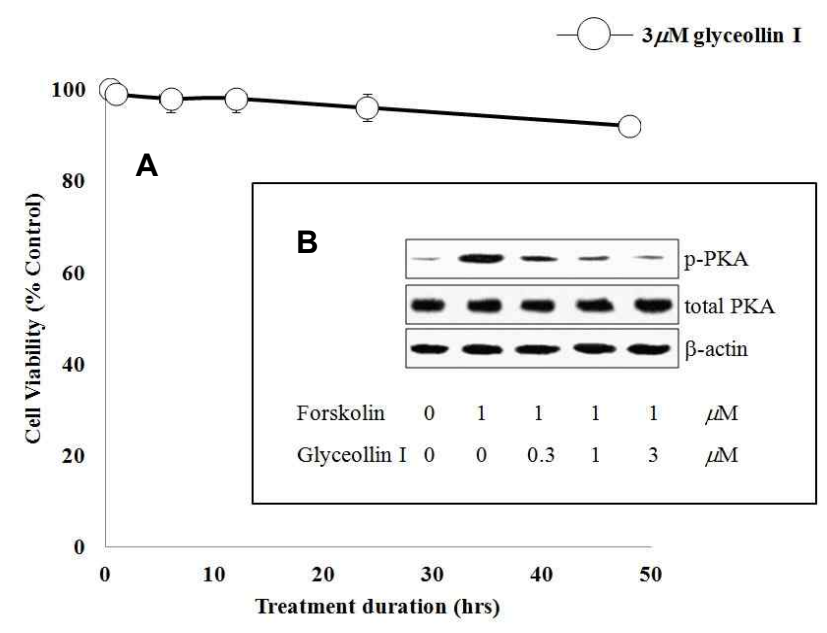

Fig. 5. (A) The viability of B16F10 cells during the glyceollin I treatments. Cells were treated over the indicated time (from 0 to $48 \mathrm{~h}$ ) with $3 \mu \mathrm{M}$ of glyceollin I. The viability was evaluated by MTT assay and represented as percentages of control. The data are in the standard error of the mean of the assay triplicates and (B) Glyceollin I attenuated PKA activation in B16F10 melanoma cells treated with forskolin. Western blotting was done by using the phospho-specific antibody pSer 96 (pPKA). One representative blot is shown from three experiments that yielded similar results.

\section{The effect of glyceollin I on melanocyte viability}

The data from the cell viability assay using MTT for B16F10 cells are shown in Fig. 5A. The B16F10 cells were treated for $48 \mathrm{~h}$ at higher effective concentration of glyceollin I $(3 \mu \mathrm{M})$. Longterm treatment of glyceollin I did not induce any cellular damage strongly suggesting that the anti-melanogenesis effect of glyceollin I is not due to its cytotoxicity.

The effect of glyceollin | on forskolin-induced PKA phosphorylation

The total level of forskolin-induced PKA phosphorylation (pPKA) was measured in the presence or absence of glyceollin I. Fig. 5B shows that glyceollin I treatment significantly down-regulated the level of pPKA. These results clearly tell us that glyceollin I effectively blocks mAC which is the upstream key enzyme of the cAMP-pPKA melanogenesis pathway.

\section{Discussion}

Enzymes and receptors most often show high specificities for their substrates and agonists, respectively. In drug design, however, it is most important to realize that ligands are recognized by their chemical properties, not by their molecular structure. Various ligands which exert similar interactions with the functional groups of the active binding site have similar affinities, even if their chemical structures are quite different. As shown in this study, even though the chemical structure of two compounds are not similar (Fig. 1 and 2A), glyceollin I exhibited same molecular targeting and inhibitory effect on $\mathrm{mAC}$ as SQ22,536.

Although hydrophobic interactions between lipophilic surfaces of a ligand and hydrophobic areas of its binding site always contribute to affinity in a positive manner, the influence of hydrogen bonding needs a more careful inspection. Binding of the ligand to its specific site will be favored if the energy of the hydrogen bonds in the complex and the entropy gain in releasing some bound water molecules are more favorable than the free-energy contribution of the hydrogen bonds between the binding partners, in their free state, and these water molecules. The proposed binding modeling in this study, glyceollin I connected more hydrogen-bonds (Asp1018, Trp1020, and Asn1025) with mAC (Fig. 2), likewise, inhibited $\mathrm{mAC}$-induced cAMP production more effectively than SQ22,536 did (Fig. 4). It is also very important to check whether the similar structure to glyceollin I (or similar chemical which dosen't have hydrogen bonding) interacts to $\mathrm{mAC}$ in order to present the specificity of glyceollin I in further study.

In addition, glyceollin I not only reduced the level of cAMP content but also suppressed PKA phosphylation (Fig. 5B). cAMP-related melanogenesis has been reported to be mediated by phosphorylation and activation of the cAMP response element binding protein (CREB) family transcription factors by PKA. The binding of CREB to the promoter site of MITF leads to the indirect activation of the tyrosinase promoter by microphthalmia related transcription factor (MITF). According to the previous reports [9, 11], glyceollin I's effect led to the inhibition of tyrosinase levels and subsequently resulted in supression of melanogenesis $[9,13]$. Overall, the elucidation of the hydrogen-binding site property of glyceollin I on mAC could provide a structural basis for the pharmacological modulation of $\mathrm{mACs}$ and clues for the treatment related incurable skin diseases. Glyceollin I's inhibitory effect on mAC may be applicable to develop anti-melanogenic agent for the prevention and treatment of skin pigmentation. Thus, glyceollin I can be considered as a novel and potent $\mathrm{mAC}$ inhibitor and skin-lightening agent without any cytotoxicity (Fig. 5A). 


\section{Acknowledgments}

This work was supported by the R\&D Support Program (NXRND \#20120901) of NEURONEX. Co. Ltd. We give special thanks to Mrs. Sunok Kim, CEO of the NEURONEX.

\section{References}

1. Boue, S. M., Carter, C. H., Ehrlich, K. C. and Cleveland, T. E. 2000. Induction of the soybean phytoalexins coumestrol and glyceollin by Aspergillus. J Agric Food Chem 48, 2167-2172.

2. Brown, B. L., Albano, J. D., Ekins, R. P. and Sgherzi, A. M. 1971. A simple and sensitive saturation assay method for the measurement of adenosine $3^{\prime}: 5^{\prime}$-cyclic monophosphate. Biochem J 121, 561-562.

3. Busca, R. and Ballotti, R. 2000. Cyclic AMP a key messenger in the regulation of skin pigmentation. Pigment Cell Res 13, 60-69.

4. Cheli, Y., Luciani, F., Khaled, M., Beuret, L., Bille, K., Gounon, P., Ortonne, J. P., Bertolotto, C. and Ballotti, R. 2009. alpha-MSH and Cyclic AMP elevating agents control melanosome $\mathrm{pH}$ through a protein kinase A-independent mechanism. J Biol Chem 284, 18699-18706.

5. Daniel, O., Meier, M. S., Schlatter, J. and Frischknecht, P. 1999. Selected phenolic compounds in cultivated plants: ecologic functions, health implications, and modulation by pesticides. Environ Health Perspect 107 Suppl 1, 109-114.

6. Dwivedi, Y. and Pandey, G. N. 2008. Adenylyl cyclase-cyclicAMP signaling in mood disorders: role of the crucial phosphorylating enzyme protein kinase A.
Neuropsychiatr Dis Treat 4, 161-176.

7. Gillbro, J. M. and Olsson, M. J. 2011. The melanogenesis and mechanisms of skin-lightening agents-existing and new approaches. Int J Cosmet Sci 33, 210-221.

8. Graham, T. L. and Graham, M. Y. 1996. Signaling in soybean phenylpropanoid responses (Dissection of Primary, Secondary, and Conditioning Effects of Light, Wounding, and Elicitor Treatments). Plant Physiol 110, 1123-1133.

9. Han, Y. K., Park, Y. J., Ha, Y. M., Park, D., Lee, J. Y., Lee, N., Yoon, J. H., Moon, H. R. and Chung, H. Y. 2012. Characterization of a novel tyrosinase inhibitor, (2RS,4R)-2-(2,4-dihydroxyphenyl)thiazolidine-4-carboxylic acid (MHY384). Biochim Biophys Acta 1820, 542-549.

10. Iwatsubo, K., Tsunematsu, T. and Ishikawa, Y. 2003. Isoform-specific regulation of adenylyl cyclase: a potential target in future pharmacotherapy. Expert Opin Ther Targets 7, 441-451.

11. Kim, D. C., Rho, S. H., Shin, J. C., Park, H. H. and Kim, D. 2011. Inhibition of melanogenesis by 5,7-dihydroxyflavone (chrysin) via blocking adenylyl cyclase activity. Biochem Biophys Res Commun 411, 121-125.

12. Kim, H. J., Lim, J. S., Kim, W. K. and Kim, J. S. 2012. Soyabean glyceollins: biological effects and relevance to human health. Proc Nutr Soc 71, 166-174.

13. Prezioso, J. A., Hearing, V. J., Muller, J., Urabe, K., Wang, N. and Gorelik, E. 1995. Impairment of the melanogenic pathway in B16 melanoma cells transfected with class I H-2 genes. Melanoma Res 5, 15-25.

14. Yoon, W. J., Kim, M. J., Moon, J. Y., Kang, H. J., Kim, G. O., Lee, N. H. and Hyun, C. G. 2010. Effect of palmitoleic acid on melanogenic protein expression in murine b16 melanoma. J Oleo Sci 59, 315-319. 
초록 : 글리세올린 의 아데니닐 고리화 효소 활성 억제 효능과 결합 부위 비교 분석

김동찬 ${ }^{1} \cdot$ 김남두 $^{2} \cdot$ 김성인 $^{1} \cdot$ 장철수 ${ }^{1}$ 권창오 ${ }^{1} \cdot$ 김병원 $^{1}$, 류재기 $^{1} \cdot$ 김현경 $^{1} \cdot$ 이석준 ${ }^{1} \cdot$ 이승호 ${ }^{3} \cdot$ 김동진 $^{4}$

( ${ }^{1}$ 김천대학교 임상병리학과, ${ }^{2}$ 대구경북첨단의료복합단지 신약개발지원센터, ${ }^{3}$ 김천대학교 한방재활학과,

${ }^{4}$ 미국 조지아 공과대학교 도시환경공학과)

글리세올린 I 은 다양한 피부 질환의 예방과 치료에 유용한 물질로 주목을 받아왔다. 그러나 피부 멜라닌 형성 에 결정적 역할을 담당하는 포유류의 아데니닐 고리화 효소(이하 $\mathrm{mAC}$ )에 대한 직접적인 결합 형태와 상호 작용 에 대한 연구는 현재까지 연구 보고된 사례가 없었다. 글리세올린 I 의 $\mathrm{mAC}$ 활성 부위에 대한 결합 작용 기작을 규명하기 위하여 우선 글리세올린 I과 SQ22,536 ( $\mathrm{mAC}$ 에 결합하여 $\mathrm{mAC}$ 의 활성을 억제하는 것으로 이미 잘 알려 진 단일 화합 물질)의 $\mathrm{mAC}$ 에 대한 결합 친화도와 결합 형태를 비교 분석 하였다. 글리세올린 $\mathrm{I}$ 은 $\mathrm{mAC}$ 의 활성부 위에 존재하는 Asp 1018, Trp 1020, Asn 1025와 각각 3개의 수소결합을 형성하는 것으로 분석되었고 SQ22,536은 $\mathrm{mAC}$ 활성부위의 Asp 1018, Asn 1025와 2개의 수소결합을 형성하여 글리세올린 I이 상대적으로 우월하게 결합 하는 것으로 분석되었다. 글리세올린 I은 또한 포스콜린(forskolin)에 의해서 유도되는 세포내 멜라닌 형성 2차 신호전달 물질인 cyclic $\mathrm{AMP}$ 의 생성과 이로인해 유발되는 단백질 인산화 효소 $\mathrm{A}$ 의 인산화를 효과적으로 억제하 는 것을 멜라노마 세포 실험을 통하여 확인하였다. 또한 글리세올린 I 을 장시간 세포에 투여하여도 세포의 생존 률에는 영향을 주지 않음을 확인하였다. 본 연구 통하여 규명된 글리세올린 I의 $\mathrm{mAC}$ 활성 억제 효능 및 멜라닌 생성 신호전달 기작을 조절하는 성질을 이용하여 향후 흑색종과 같은 다양한 피부 질환 치료제 개발 및 미백 화장품 핵심 물질 개발에 활용될 수 있을 것으로 사료된다. 